\title{
Darjeeling Mandarin Orange: Reasons for its Decline and Perceived Constraints
}

\author{
Rakesh Roy ${ }^{*}$, Basu Deo Kharga and Mendel Wangchuk Moktan \\ Darjeeling Krishi Vigyan Kendra, Uttar Banga Krishi Viswavidyalaya, Kalimpong-734301, \\ West Bengal, India \\ *Corresponding author
}

\section{A B S T R A C T}

The study was undertaken with the objectives to assess reasons for mandarin decline and perceived constraints of the mandarin orange growers. The study was purposively conducted in the hill region of Darjeeling district in West Bengal where Darjeeling mandarin orange is the pride fruit of the region. In all, 150 respondents were considered for the study further 30 key respondents were also included in the study to understand evidently the reasons for decline in mandarin orange production. The study shows that

\section{Keywords}

Darjeeling hills, Mandarin orange, Reasons for decline, Perceived constraints

Article Info

Accepted: 14 August 2018 Available Online: 10 September 2018 weak farm management and lack of irrigation facility as perceived by key respondents and lack of irrigation and low availability of hired labour as perceived by mandarin growers were the major socio-economic reasons for mandarin decline in the study area. Old and nutrient-exhausted farms; problem of foot and root rot, powdery mildew and low soil nutrient content as perceived by key informants and problem of trunk borer, fruit fly, leaf eating caterpillar, leaf miner and problem of foot and root rot, powdery mildew as perceived by mandarin growers were the major biological reasons for mandarin decline. Long dry spells during winter lasting until flowering and temperature rise and shift in seasons as perceived by key informants and long dry spells during winter lasting until flowering and drying springs or streams near plantations as perceived by mandarin growers were the major environmental reasons for mandarin decline. Lack of local intuition for growers and lack of forward and backward linkages as perceived by key informants whereas mandarin growers had perceived lack of policy support for mandarin cultivation, lack of extension services and lack of institution for growers were the major institutional reasons for mandarin decline. Further, lack of regular water supply for irrigation was perceived as the major technical constraints and lack of credit facility was the major economic constraints. The existence of middleman was the major marketing constraints and poor quality of water was the major general constraints perceived by the mandarin growers.

\section{Introduction}

India is the second largest producer of fruits in the world. Its share in world's fruit production is $11 \%$ (Yadav et al., 2013). Citrus has third highest production after banana and mango and major fruit growing states are Tamil Nadu, Maharashtra, Gujrat Karnataka, Uttar Pradesh, Bihar, Madhya Pradesh and West Bengal (Rao, 2013). Mandarin orange also 
known as the mandarin or mandarine is one of the premier commercial citrus grown in India. Numerous research works have been done in the country on various aspects such as varieties, propagation, irrigation and pruning for stabilizing and increasing the production, productivity and quality of mandarin fruits (Yadav et al., 2013).

In spite of availability of improved mandarin production technologies and proper management practices, there is huge gap between the yield of mandarin orchard at the research farm and at farmer's field.

It is obvious that improved practices are not only the factors which cause adoption or rejection but constraints in production may be the reason for low adoption or rejection of latest mandarin production technologies. Therefore, the study was undertaken with the objective to assess local actors' perceptions for mandarin decline in production area and productivity and the perceived constraints of the mandarin orange growers.

\section{Materials and Methods}

\section{Study location}

The study was conducted in the hill region of Darjeeling district in West Bengal which is located between latitude $27^{\circ} 13^{\prime} \mathrm{N}$ to $26^{\circ} 27^{\prime}$ $\mathrm{N}$ and longitude $88^{\circ} 53^{\prime} \mathrm{E}$ to $87^{\circ} 59^{\prime} \mathrm{E}$. Undivided Darjeeling district is spread over 3149 square kilometers. The terrain in the district is both hilly and plain. The temperature ranges between $24{ }^{\circ} \mathrm{C}$ to $14^{\circ} \mathrm{C}$ in summer, and between $8^{\circ} \mathrm{C}$ to $5^{\circ} \mathrm{C}$ in winter. The hill areas get heavy rainfall in the monsoons. Average rainfall is 2831.9 millimeter and average numbers of rainy days are 106 days (Anonymous, 2012). The altitude of Darjeeling town is 2134 meters above sea level.

\section{Study design}

The study was purposively conducted at Takdah, Mirik and Kurseong block of Darjeeling district due to its high production and area under cultivation of Darjeeling mandarin. Respondents (50 per blocks) were randomly selected for the study. Thus, the total respondents for the study were 150 . Further 30 key respondents (scientists, extension workers and progressive farmers) were also included in the study to understand evidently the reasons for decline in mandarin orange production. The interview was completed through farm visits.

\section{Data analysis}

Data was coded and entered into excel spreadsheets and simple statistical analysis such as frequency and percentage was performed using SPSS 20 software.

Garrett's Ranking Technique (Garrett, 1981) has been used to analyze the perceived constraints in adoption of improved production technologies in Darjeeling mandarin. The respondents were asked to rank the probable constraints. The order of merit, assigned by respondents was converted into ranks by using the following formula,

Percent position of each rank $=100\left(\mathrm{R}_{\mathrm{ij}}{ }^{-}\right.$ $0.05) / \mathrm{N}_{\mathrm{j}}$,

Where $R_{i j}=$ Rank given for the $i^{\text {th }}$ factors for the $\mathrm{j}^{\text {th }}$ respondent.

$\mathrm{N}_{\mathrm{j}}=$ Number of factors ranked by the $\mathrm{j}^{\text {th }}$ respondent

The percentage position of each rank obtained is converted into scores by referring to the table given by Henry Garrett. Then for each factors the scores of individual respondents were added together and divided by the total 
number of the respondents for whom the score were added. These mean scores (MS) for all the factors were arranged in order of merit and inference drawn.

\section{Results and Discussion}

\section{Major reasons perceived for mandarin declines}

The perceived reason for mandarin decline was assessed in terms of socio-economic reason, biological reason, environment or climate related reasons and institutional related reasons (Table 1). The study shows the major reasons for decline in Darjeeling mandarin as per key respondents were weak farm management $(93.33 \%)$ and lack of irrigation facilities $(93.33 \%)$ whereas mandarin growers had perceived lack of irrigation facilities (93.33\%) and low availability of hired labour $(76.67 \%)$ were the major socio-economic reasons for mandarin decline.

Among biological reasons such as old and nutrient-exhausted farms $(93.33 \%)$, problem offoot and root rot, powdery mildew (90\%) and low soil nutrient content or fertility (90\%) were the major reasons for mandarin decline as perceived by key informants whereas mandarin growers had perceived problem of trunk borer, fruit fly, leaf eating caterpillar, leaf miner (90\%) and problem of foot and root rot, powdery mildew $(88.67 \%)$ were the major biological reasons for mandarin decline.

De (2017) reported that planting of trees in steep slopes and heavy rainfall and lack of supplementary application of nutrients cause gradual decrease in soil fertility. Deficiency of phosphorous, zinc, magnesium, boron, molybdenum, calcium etc.in soil causes decline in production and dieback in NE region of India. Singh et al., (2016) reported that the major cause, however, is the prevalence of insect/ pest, some fungal, bacterial and viral diseases which have a significant impact and often become a major constraint in mandarin production.

Among environmental or climate related reasons such as long dry spells during winter lasting until flowering (70\%) and temperature rise and shift in seasons $(53.33 \%)$ were the major reasons perceived by key informants whereas mandarin growers had perceived long dry spells during winter lasting until flowering $(84.67 \%)$ and drying springs or streams near plantations $(81.33 \%)$ were the major environmental reasons for mandarin decline.

De (2017) reported that heavy and long spells of rainfall causes damage during flowering and fruit setting further it favours development of mosses, lichens and fungal pathogens. Mahanta and Konwar (2014) reported that maximum growers faced climatic problems such as wind and storms, drought etc.

Among institutional related reasons lack of local intuition for growers $(53.33 \%)$ and lack of forward and backward linkages (46.67\%) were the major reasons for mandarin decline as perceived by key informants whereas mandarin growers had perceived lack of policy support for mandarin cultivation (94.67\%), lack of extension services $(92.67 \%)$ and lack of institution for growers were the major institutional reasons for mandarin decline.

\section{Perceived constraints by mandarin growers}

Garret ranking techniques was used to rank the perceived constraints of mandarin growers in Darjeeling hills. The constraints were assessed in term of technical constraints, economic constraints, storage and marketing constraints and general constraints as perceived by the mandarin growers in the district (Table 2). 
Table.1 Major reasons perceived for decline in Darjeeling mandarin

\begin{tabular}{|c|c|c|c|}
\hline \multirow{2}{*}{$\begin{array}{l}\text { Sl. } \\
\text { No. }\end{array}$} & \multirow[t]{2}{*}{ Factors } & \multicolumn{2}{|c|}{ Perception by the respondents } \\
\hline & & $\begin{array}{c}\text { Key } \\
\text { Informants } \\
(\mathbf{n}=\mathbf{3 0})\end{array}$ & $\begin{array}{l}\text { Mandarin } \\
\text { growers } \\
(\mathbf{n}=150)\end{array}$ \\
\hline A. & \multicolumn{3}{|c|}{ Socio-economic } \\
\hline 1. & Weak farm management & 28(93.33) & $71(47.33)$ \\
\hline 2. & Land fragmentation & $7(23.33)$ & 73(48.67) \\
\hline 3. & Lack of irrigation facilities & 28(93.33) & 141(94.00) \\
\hline 4. & High cost of FYM & $12(40.00)$ & $93(62.00)$ \\
\hline 5. & Low availability of hired labour & $5(16.67)$ & $115(76.67)$ \\
\hline B. & \multicolumn{3}{|l|}{ Biological } \\
\hline 1. & Low crop productivity & $21(70.00)$ & 136(90.67) \\
\hline 2. & Foot and root rot, powdery mildew & $27(90.00)$ & 133(88.67) \\
\hline 3. & $\begin{array}{l}\text { Trunk borer, fruit fly, leaf eating caterpillar, leaf } \\
\text { miner }\end{array}$ & $26(88.67)$ & $135(90.00)$ \\
\hline 4. & Mammalian pests & 516.67) & $66(44.00)$ \\
\hline 5. & Low soil nutrient content or fertility & $27(90.00)$ & $102(68.00)$ \\
\hline 6. & $\begin{array}{l}\text { Decreased number of pollinators (due to climate } \\
\text { change impacts) }\end{array}$ & $22(73.33)$ & $67(44.67)$ \\
\hline 7. & Old and nutrient-exhausted farms & 28(93.33) & $82(54.67)$ \\
\hline 8. & Lack of disease-free planting materials & 19(63.33) & $43(28.67)$ \\
\hline C. & \multicolumn{3}{|c|}{ Environmental or climate } \\
\hline 1. & Erratic or uneven rainfall & $14(46.67)$ & $35(23.33)$ \\
\hline 2. & $\begin{array}{l}\text { Long dry spells during winter lasting until } \\
\text { flowering }\end{array}$ & 21(70.00) & 127(84.67) \\
\hline 3. & Temperature rise or shift in seasons & $16(53.33)$ & 41(27.33) \\
\hline 4. & Air pollution & $2(6.67)$ & $6(4.00)$ \\
\hline 5. & Frost or hail & 1(3.33) & 21(14.00) \\
\hline 6. & Extreme heat or cold & $7(23.33)$ & $37(24.67)$ \\
\hline 7. & Drying springs or streams near plantations & 11(36.67) & $122(81.33)$ \\
\hline D. & \multicolumn{3}{|l|}{ Institutional } \\
\hline 1. & Lack of policy support for mandarin cultivation & $6(20.00)$ & 142(94.67) \\
\hline 2. & $\begin{array}{l}\text { Lack of extension services (financial/material } \\
\text { support) }\end{array}$ & $9(30.00)$ & 139(92.67) \\
\hline 3. & Lack of local institutions for growers & $16(53.33)$ & 118(78.67) \\
\hline 4. & Lack of forward and backward linkages & 14(46.67) & 107(71.33) \\
\hline 5. & Lack of training & $9(30.00)$ & 110(73.33) \\
\hline 6. & Lack of research on mitigating disease problems & $6(20.00)$ & 109(72.67) \\
\hline
\end{tabular}

Figures in parenthesis indicate percentage 
Table.2 Perceived constraints of mandarin growers of Darjeeling hills

\begin{tabular}{|c|c|c|c|c|}
\hline Sl. No. & Constraints & Score & Mean Score & Rank \\
\hline A. & \multicolumn{4}{|l|}{ Technical constraints } \\
\hline 1. & Lack of regular water supply for irrigation & 8665 & 57.77 & I \\
\hline 2. & Plant is diseases sensitive & 7770 & 51.80 & III \\
\hline 3. & Lack of technical knowledge & 7197 & 47.98 & VI \\
\hline 4. & Low productivity of plant & 8379 & 55.86 & II \\
\hline 5. & Long vegetative period & 7281 & 48.54 & V \\
\hline 6. & High mortality of plant during initial stages & 7767 & 51.78 & IV \\
\hline 7. & Soil is not suitable for orange & 5891 & 39.27 & VII \\
\hline B. & \multicolumn{4}{|l|}{ Financial constraints } \\
\hline 1. & Lack of credit facility & 9105 & 60.70 & I \\
\hline 2. & Costly planting material & 7770 & 51.80 & III \\
\hline 3. & High insecticide and pesticides cost & 7197 & 47.98 & VI \\
\hline 4. & High cost of transportation for fruit and planting material & 8581 & 57.21 & II \\
\hline 5. & Labour intensive crop & 7281 & 48.54 & $\mathrm{~V}$ \\
\hline 6. & High establishment cost at initial stage & 7407 & 49.38 & IV \\
\hline 7. & Perishable product & 5609 & 37.39 & VII \\
\hline C. & \multicolumn{4}{|c|}{ Storage and marketing constraints } \\
\hline 1. & Lack of proper market & 8489 & 56.59 & II \\
\hline 2. & Market prices is highly fluctuated & 7342 & 48.95 & $\mathrm{~V}$ \\
\hline 3. & Existence of middleman & 8770 & 58.47 & I \\
\hline 4. & No preservation industry & 7698 & 51.32 & III \\
\hline 5. & Lack of storage facility & 6211 & 41.41 & VII \\
\hline 6. & No co-operative marketing system & 7375 & 49.17 & IV \\
\hline 7. & Low purchasing power of the consumer & 7065 & 47.10 & VI \\
\hline D. & \multicolumn{4}{|l|}{$\begin{array}{ll}\text { General constraints } \\
\end{array}$} \\
\hline 1. & Poor quality of water & 8381 & 55.87 & I \\
\hline 2. & Threat from wild and stray animal & 7378 & 49.18 & V \\
\hline 3. & Undulated land & 7223 & 48.15 & VI \\
\hline 4. & Small land holding & 7809 & 52.06 & II \\
\hline 5. & Chances of theft & 7051 & 47.01 & VII \\
\hline 6. & Non availability of approach road & 7611 & 50.74 & III \\
\hline 7. & Reluctance for fruit growing & 7497 & 49.98 & IV \\
\hline
\end{tabular}

Among technical constraints mandarin growers had perceived that lack of regular water supply for irrigation (MS=57.77) was the major constraint followed by low productivity of plant (MS=55.86) and diseases sensitive plant $(\mathrm{MS}=51.80)$. Anavrat (2015) reported that inadequate irrigation was the major constraints in Nagpur mandarin farming in Rajasthan. Meena et al., (2017) found that high incidence of insect pest was observed as most serious constraints followed by citrus die back, lack of knowledge about package of practices and non-availability of trained labour among the technological constraints. 
Among financial constraints mandarin growers had perceived that lack of credit facility (MS=60.70) was the major constraint followed by high cost of transportation for fruit and planting material $(\mathrm{MS}=57.21)$ and costly planting material (MS=51.80). De (2017) reported that high capital cost involvement for establishment of orchard and infrastructure, less expenditure on research work and lack of insurance facilities in the citrus were common financial constraints. Transportation of perishable products was another serious constraint in NE region of India. Meena et al., (2017) found that lack of awareness was most serious constraint followed by cheating pesticide dealers, high cost of inputs and high cost of labour among socio- economic constraints.

Among storage and marketing constraints, mandarin growers had perceived that existence of middleman (MS=60.70) was the major constraint followed by lack of proper market $(\mathrm{MS}=58.47)$ and no preservation industry $(\mathrm{MS}=56.59)$ in the study area. De (2017) reported that there was no network of organized market in NE region of India and the farmers used to get low return by selling their perishable produce at throw way prices to middlemen. Bhople et al., (1996) found that orange growers faced marketing constraints like costly packaging material (80\%), non-availability of processing units (76.67\%) and high transportation charges for transporting fruit from orchards to nearby market (54.9\%).

Among general constraints mandarin growers had perceived that poor quality of water (MS=55.87) was the major constraint followed by small land holding (MS=52.06) and non-availability of approach road (MS=50.74). Khan et al., (2007) reported that unavailability of electricity for irrigation, higher input cost especially diesel and limited sources of information were the major constraints faced by farmers of NarsingKheda village of Sihore district.

The study has pointed out the major reasons for Darjeeling mandarin decline and perceived constraints faced by the growers of this region. Now, it is the high time to work on major reasons for mandarin decline. The policy makers should plan and implement appropriate strategies to reduce the constraints of mandarin grower of this region. Further, extension agencies working in the study area should also come up with appropriate technologies addressing the problems and constraints of mandarin growers in the region so that the pride fruit of this region may regain its production and productivity to its maximum.

\section{References}

Anavrat, V. (2015). Adoption, correlates and constraints of Nagpur mandarin farming in Rajasthan, Agriculture Update, 10(1): 61-64

Anonymous. (2012). Gorkhaland Territorial Administration Sabha Election - 2012. Information booklet. Government of West Bengal, Office of the Election Officer \& District Magistrate, Darjeeling.

Bhople RS, Shinde PS and Nimje VR. (1996). Production and marketing constraints faced by orange growers, Maharashtra Journal of Extension Education, 15: 5762.

De LC. (2017). Citrus rejuvenation in NE region of India, International Journal of Agricultural Science and Research, 7(2): $325-342$

Garrett HE. (1981). Statistics in Psychology and Education. Published by Vakils, Feffer and Simons Ltd., Mumbai.

Khan AR, Dubey MK, Bisen PK and Saxena KK. (2007). Constraints faced by farmers of NarsingKheda village of 
Sihore district, Indian Research Journal of Extension Education, 7 (1): 57-59

Mahanta DK and Konwar A. (2014). Production and marketing of orange in Assam - A study on Doomdooma region of Tinsukia district, Journal of Agriculture and Life Sciences, 1(1): 8290

Meena RR, Geanger KL, Meena BL, Bhatnagar P and Meena PL. (2017). Analysis of adoption and constraint perceived by mandarin growers in Jhalawar district of Rajasthan state, India, International Journal of Current Microbiology and Applied Sciences, 6(4): 1465-1470

Rao BSN. (2013). Fruits, vegetables, milk and animal food in balanced Indian diets-a critical appraisal, Nutrition Foundation of India Bulletin, 34(1): 1-5.

Singh AK, Meetei NT, Singh BK and Mandal N. (2016). Khasi mandarin: its importance, problems and prospects of cultivation in North-Eastern Himalayan region, International Journal of Agriculture, Environment and Biotechnology, 9(4): 573-59210. 5958/2230-732X.2016.00076.0

Yadav BC, Choudhary R and Saran PL. (2013). Adoption of improved production technology of Mandarin in Rajasthan, India: A review, African Journal of Agricultural Research, 8(49): 6590-6600

\section{How to cite this article:}

Rakesh Roy, Basu Deo Kharga and Mendel Wangchuk Moktan. 2018. Darjeeling Mandarin Orange: Reasons for its Decline and Perceived Constraints. Int.J.Curr.Microbiol.App.Sci. 7(09): 14-20. doi: https://doi.org/10.20546/ijcmas.2018.709.003 